\title{
Significance of Chemical Priming on Yield and Yield Components of Wheat under Drought Stress
}

\author{
Alam Sher ${ }^{1,2 *}$ Aaqil khan', Sajid Hussain ${ }^{3}$, Li Jin Cai', Muhammad Irfan Ahmad1, \\ Sikandar Ali Jamro' ${ }^{1}$, Arif Rashid ${ }^{4}$ \\ ${ }^{1}$ Anhui Agricultural University, School of Agronomy, Hefei, China; \\ ${ }^{2}$ Ayub Agricultural Research Institute, Faisalabad, Pakistan \\ ${ }^{3}$ College of Agriculture, BZU Bahadur Sub Campus, Layyah, Pakistan \\ ${ }^{4}$ Department of Crop Biotechnology, Anhui Agricultural University, Hefei, China \\ Email: *sherjunaid1855@yahoo.com
}

How to cite this paper: Sher, A., khan, A. Hussain, S., Cai, L.J., Ahmad, M.I., Jamro, S.A. and Rashid, A. (2017) Significance of Chemical Priming on Yield and Yield Components of Wheat under Drought Stress. American Journal of Plant Sciences, 8, 13391344.

https://doi.org/10.4236/ajps.2017.86090

Received: April 5, 2017

Accepted: May 22, 2017

Published: May 25, 2017

Copyright $\odot 2017$ by authors and Scientific Research Publishing Inc. This work is licensed under the Creative Commons Attribution-NonCommercial International License (CC BY-NC 4.0). http://creativecommons.org/licenses/by-nc/4.0/

\begin{abstract}
Drought is the most important factor limiting plant production in the majority of agricultural crops of the world. Wheat is generally grown on arid-agricultural fields. An experiment was conducted at the Plant physiology research area, Agronomic Research Institute Faisalabad, during winter 2010-11 to evaluate the effect of drought on wheat variety Lasani 2008 . The experiment was comprised of following treatments. $\mathrm{T}_{1}$ Normal moisture (3 IR at CRS, Booting and grain filling), $T_{2}$ No irrigation (only rainfed) control, $T_{3}$ water spray (100 $\mathrm{ppm}), \mathrm{T}_{4}$ ascorbic acid $(100 \mathrm{ppm}), \mathrm{T}_{5}$ salicylic acid $(100 \mathrm{ppm}), \mathrm{T}_{6}$ calcium chloride $(100 \mathrm{ppm}), \mathrm{T}_{7}$ glycinbetain $(100 \mathrm{ppm})$. According to the resulting data the treatment in which three irrigation were applied produced more no. of tillers (52\%), spikelet per spike (41\%), spike length (30\%), grain per spike (58\%), grain yield (54\%), biological yield (35\%) as compared to control. The treatment in which no irrigation was applied produced less no. of tillers, spikelet per spike, spike length, grain per spike, grain yield, biological yield. Thousand grain weight and harvest index were non significant among all treatments.
\end{abstract}

\section{Keywords}

Wheat, Hormonal Priming, Drought, Ascorbic Acid, Salicylic Acid, Calcium Chloride, Glycinbetain

\section{Introduction}

Drought stress is characterized by reduction of water content, diminished leaf 
water potential, turgor loss, closure of stomata, decrease in cell enlargement and growth [1]. Severe water stress may result in the arrest of photosynthesis, disturbance of metabolism and finally the death of plants [2]. Plant growth is accomplished through cell division, cell enlargement and differentiation, which involve genetic, physiological, ecological and morphological events; sensitive to drought [3]. Water stress reduces plant growth and manifests several morphological, physiological and biochemical alterations leading to massive loss in yield [4]. Water shortage at critical growth stages such as crown root initiation, tillering, booting, anthesis and grain filling has deleterious effects on plant growth, development and economic yield of wheat [5] [6]. Wheat grain yield and yield components such as productive tillers, grains per spike, kernel weight, biological yield and harvest index are the attributes, which are adversely affected by soil moisture stress [4] [7] [8] [9]. Water deficit hampers photosynthesis due to reduced synthesis of chlorophyll pigments resulting in declined light harvesting reaction [10]. The other causes of reduction in photosynthetic rate are decrease in leaf expansion, impaired photosynthetic machinery, reduced influx of $\mathrm{CO}_{2}$ due to low stomatal conductance and premature leaf senescence. Water stress lowers water potential, osmotic potential and pressure potential of wheat leaves [7]. Water stress mostly reduces leaf growth and in turn leaf area in many plant species [8].

Many strategies are being practised in the world to cope with water scarcity; exogenous application of compatible solutes is the one that is getting considerable attention in present-day agricultural research [11] [12]. However, seed priming is cheapest approach to cope with adverse effect of abiotic stresses at different developmental stages of crop [9] [13] [14]. There are different priming techniques such as hormonal priming hydropriming and osmopriming [14] [15] [16] [17].

Plant growth regulators, hormones and hormones like substances for example ascorbic acid, salicylic acid, glycinbetain used as seed priming to reduce the adverse effect of abiotic stresses in different cropes [14] [15]. The relative effectiveness of different priming agents varies with different stresses and different crop species is unclear. Moreover biochemical and physiological roles of ascorbic acid, salicylic acid, calcium chloride and glycinbetain on drought tolerance of wheat as pre seed treatment is limited. The objective of this paper was to check ameliorating effects of pre sowing treatments on wheat yield.

\section{Material and Methods}

\subsection{Experimental Site}

A field experiment was conducted at the Agronomic Research Institute, Plant Physiology Section, Ayub Agricultural Research Institute (AARI), Faisalabad during Rabi 2010-11.

\subsection{Experimental Material}

The soil of this experimental area was loam to sandy loam. Variety was Lasani 
2008. The experiment was laid out in randomized complete block design (RCBD) with three replications and seven treatments. Sowing with hand drill. Before final land preparation nitrogen and phosphorus were applied at the rate of 24-60 kg per hectare and the source of fertilizers were Urea and DAP. The seed was $50 \mathrm{~kg}$ per hectare and row spacing was $30 \mathrm{~cm}$. Main plot size was $12 \mathrm{~m}$ $\times 7.2 \mathrm{~m}$ and sub plot size was $4 \mathrm{~m} \times 2.4 \mathrm{~m}$ (Table 1$)$.

Table 1. Physico-chemical soil analysis of crop area.

\begin{tabular}{ccccc}
\hline Characteristics & \multicolumn{4}{c}{ Soil sample depth } \\
\hline Soil Ph & $10 \mathrm{~cm}$ & $15 \mathrm{~cm}$ & $20 \mathrm{~cm}$ & Mean \\
Organic matter (\%) & 7.7 & 7.9 & 8 & 7.8 \\
Total nitrogen (\%) & 0.066 & 1.35 & 1.02 & 1.23 \\
Available P (mg $\left.\cdot \mathrm{kg}^{-1}\right)$ & 4.2 & 0.048 & 0.058 & 0.057 \\
Available $\mathrm{k}\left(\mathrm{mg} \cdot \mathrm{kg}^{-1}\right.$ ) & 186 & 7.3 & 9.8 & 7.1 \\
Texture & Loam to sandy loam Loam to sandy loam Loam to sandy loam & \\
\hline
\end{tabular}

\subsection{Seed Chemical Priming Treatments}

The seeds were surface sterilized with $1.0 \%$ solution of sodium hypochlorite for three minutes and residual chlorine was washed with disttle water. The sterilized seed were soaked in the priming solutions for a period of 12 hours at room temperature. The experiment was comprised of following treatments. $T_{1}$ Normal moisture ( 3 IR at CRS, Booting and grain filling), $T_{2}$ No irrigation (only rainfed) control, $\mathrm{T}_{3}$ water spray $(100 \mathrm{ppm}), \mathrm{T}_{4}$ seed priming with ascorbic acid (100 $\mathrm{ppm}), \mathrm{T}_{5}$ seed priming with salicylic acid (100 ppm), T6 seed priming with calcium chloride (100 ppm), T7 seed priming with glycinbetain (100 ppm).

\subsection{Parameters Studied}

At maturity, no. of tillers, spikelet per spike, spike length, grain per spike, thousand grain weight, grain yield, biological yield and harvest index were computed.

\subsection{Statistical Analysis}

The data was statistically analyzed using Analysis of Variance (ANOVA) technique and least significance Difference (LSD) test $(P<0.05)$ using MSTATC software.

\section{Results and Discussion}

\subsection{No. of Tillers}

Tillering is an important yield component. In general more no. of tillers ensure better crop stand and ultimately the yield. Response of total no. of tillers of wheat with irrigations is significant. The results are illustrated in Table 2. Maximum no. of tillers (378.9) was recorded where 3 irrigations are applied. Seed 
Table 2. Chemical priming effect on wheat yield under drought stress.

\begin{tabular}{ccccccccc}
\hline Treatments & $\begin{array}{c}\text { No. of } \\
\text { tillers }\end{array}$ & $\begin{array}{c}\text { No. of } \\
\text { Spikelets } \\
\text { per spike }\end{array}$ & $\begin{array}{c}\text { Spike } \\
\text { length }\end{array}$ & $\begin{array}{c}\text { Grain } \\
\text { per } \\
\text { spike }\end{array}$ & $\begin{array}{c}1000 \text { grain } \\
\text { weight }\end{array}$ & $\begin{array}{c}\text { Biological } \\
\text { yield kg/ha }\end{array}$ & $\begin{array}{c}\text { Grain } \\
\text { yield } \\
\text { Kg/ha }\end{array}$ & HI \\
\hline 3 irg & $378.9 \mathrm{a}$ & $17.93 \mathrm{a}$ & $12.13 \mathrm{a}$ & $57.90 \mathrm{a}$ & 43.2 & $12740 \mathrm{a}$ & $4907 \mathrm{a}$ & 37.15 \\
$\begin{array}{c}\text { No irg (control) } \\
248.3 \mathrm{e}\end{array}$ & $12.70 \mathrm{~d}$ & $9.33 \mathrm{~b}$ & $36.50 \mathrm{e}$ & 36.27 & $9420 \mathrm{~d}$ & $3181 \mathrm{e}$ & 33.77 \\
$\begin{array}{c}\text { Water } \\
(100 \mathrm{ppm})\end{array}$ & $294.9 \mathrm{c}$ & $13.73 \mathrm{~cd}$ & $9.633 \mathrm{~b}$ & $40.93 \mathrm{~d}$ & 38.34 & 10110 & $3648 \mathrm{c}$ & 36.07 \\
$\begin{array}{c}\text { Ascorbic acid } \\
(100 \mathrm{ppm})\end{array}$ & $287.5 \mathrm{~cd}$ & $14.07 \mathrm{c}$ & $9.833 \mathrm{~b}$ & $42.77 \mathrm{~cd}$ & 39.60 & $10590 \mathrm{c}$ & $3595 \mathrm{~cd}$ & 37.2 \\
$\begin{array}{c}\text { Salicylic acid } \\
(100 \mathrm{ppm})\end{array}$ & $270.7 \mathrm{de}$ & $14.90 \mathrm{c}$ & $9.633 \mathrm{~b}$ & $44.83 \mathrm{c}$ & 39.63 & $10260 \mathrm{c}$ & $3346 \mathrm{de}$ & 38.1 \\
$\begin{array}{c}\text { Calcium } \\
\text { chloride }\end{array}$ & $273.5 \mathrm{~cd}$ & $14.80 \mathrm{c}$ & $10.20 \mathrm{~b}$ & $40.00 \mathrm{~d}$ & 39.07 & $10570 \mathrm{c}$ & $3603 \mathrm{~cd}$ & 34.07 \\
$\begin{array}{c}(100 \mathrm{ppm}) \\
\text { Glycinbetain }\end{array}$ & $323.6 \mathrm{~b}$ & $16.53 \mathrm{~b}$ & $10.33 \mathrm{~b}$ & $49.80 \mathrm{~b}$ & 44.3 & $11620 \mathrm{~b}$ & $4318 \mathrm{~b}$ & 38.2 \\
$\begin{array}{c}\text { (100 ppm) } \\
\text { LSD VALUE }\end{array}$ & 23.88 & 1.399 & 1.372 & 3.383 & 1.793 & 836.2 & 299.0 & 2.061 \\
\hline
\end{tabular}

primning with glycinbetain also produced large no of tillers. Minimum no. of tillers (248.3) were produced in treatments where no irrigation was applied. These results are similar with (Jaffar et al., 2012).

\subsection{No. of Spikelets per Spike}

The data tabulated in Table 2 regarding the no. of spikelet per spike. No. of spikelet per spike were effected markedly by application of irrigations in different levels. Minimum no. of Spikelets (12.70) were produced where no irrigation was applied and maximum no. of spiklets per spike (17.93) were produced where 3 irrigations were applied. Priming with glycinbatin produceld (16.53) spikelts per spike.

\subsection{Spike Length}

Ear size is considered as a key factor which contributes much towards final grain yield. Larger the length of ear more would be the grain produced per ear and ultimately the yield would be more. The results are illustrated in Table 2. Response of spike length of wheat to irrigation was significant. Maximum Spike length (17.93) produced where 3 irrigations were applied and minimum spike length (12.13) was recorded where no irrigation was applied. These results were similar with (Razzaq et al., 2013).

\subsection{Grain per Spike}

Grain per spike are significantly affected by irrigation system. The results are illustrated in Table 2. The treatment in which three irrigation were applied produced maximum (57.90) grain per spike and in treatment in which no irrigation was applied produced minimum (36.50) grain per spike. Priming with glycinbe- 
tain produced more no of grain per spike. These results were similar with (Razzaq et al., 2013).

\subsection{Grain Weight}

1000 grain weight is very important parameter to determine grain yield. The results are illustrated in Table 2. According to this table results were non significant. It means there is no difference among treatments.

\subsection{Biological Yield}

The effect of different irrigation level on biological yield of wheat was significant. The results are illustrated in Table 2. Minimum (9420 kg/ha) biological yield was produced where no irrigation applied and biological yield increased with increase in irrigation level and it was maximum $(12740 \mathrm{~kg} / \mathrm{ha})$ where three irrigations were applied. Priming with glycinbetain produced $(11620 \mathrm{~kg} / \mathrm{ha})$ yield.

\subsection{Grain Yield}

Grain yield is an important parameter used for evaluation of effectiveness of any treatment because grain production is ultimate objective of cereals used for feeding of human being in world. According to Table 2 the effect of different level of irrigation on wheat was significant. Maximum yield $(4907 \mathrm{~kg} / \mathrm{ha})$ was recorded where 3 irrigations were applied. Minimum grain yield $(3181 \mathrm{~kg} / \mathrm{ha})$ was recorded where no irrigation was applied. These results were similar with (Hassanein et al., 2012).

\subsection{Harvest Index}

The harvest index is a essential parameter indicating photosynthetic efficiency of crop and transformation of photosynthate into its economic yield. The results are illustrated in Table 2. According to this table results were non significant. It means there is no significant difference among treatments.

\section{Conclusion}

In conclusion, the present piece of work showed that the treatment where three irrigation were applied produced more no. of tillers, spikelet per spike, spike length, grain per spike, grain yield, biological yield as compared to control. Moreover priming with Glycinebetein also produced more no. of tillers, spikelet per spike, spike length, grain per spike, grain yield, biological yield as compared to other treatments.

\section{References}

[1] Jaleel, C.A., Manivannan, P., Kishorekumar, A., Sankar, B., Gopi, R., Somasundaram, R. and Panneerselvam, R. (2007) Alterations in Osmoregulation, Antioxidant Enzymes and Indole Alkaloid Levels in Catharanthus roseus Exposed to Water Deficit. Colloids and Surfaces B: Biointerfaces, 45, 115-121.

[2] Jaleel, C.A., Sankar, B., Murali, P.V., Gomathinayagam, M., Lakshmanan, G.M.A. 
and Panneerselvam, R. (2008) Water Deficit Stress Effects on Reactive Oxygen Metabolism in Catharanthus roseus, Impacts on Ajmalicine Accumulation. Colloids and Surfaces B: Biointerfaces, 62, 105-111.

[3] Taiz, L. and Zeiger, E. (2006) Plant Physiology. 4th Edition, Sinauer Associates Inc. Publishers, Massachusetts.

[4] Farooq, M., Wahid, A., Kobayashi, N., Fujita, D. and Basra, S.M.A. (2009) Plant Drought Stress: Effects, Mechanisms and Management. Agronomy for Sustainable Development, 29, 185-212. https://doi.org/10.1051/agro:2008021

[5] Khan, M.A. (2003) Introduction. Wheat Crop Management for Yields Maximization. Department of Agriculture, Lahore (Pak), 1-5.

[6] Manikavelu, A., Nadarajan, N., Ganesh, S.K., Gnanamalar, R.P. and Babu, R.C. (2006) Drought Tolerance in Rice: Morphological and Molecular Genetic Consideration. Plant Growth Regulation, 50, 121-138. https://doi.org/10.1007/s10725-006-9109-3

[7] Akram, H.M. (2003) Drought Tolerance of Wheat as Affected by different Growth Substances. Ph.D. Thesis, Irrigation, Chapter 2, Agriculture, Economic Survey, 2002-03, 21-22.

[8] Edward, D. and Wright, D. (2008) The Effects of Winter Water-Logging and Summer Drought on the Growth and Yield of Winter Wheat (Triticum aestivum L.) European Journal of Agronomy, 28, 234-244.

[9] Farooq, M., Irfan, M., Aziz, T., Ahmad, I. and Cheema, S.A. (2013) Seed Priming with Ascorbic Acid Improves Drought Resistance of Wheat. Journal of Agronomy and Crop Science, 199, 12-22.

[10] Jaleel, C.A., Manivannan, P., Wahid, A., Farooq, M., Juburi, H.J.A., Somasundaram, R. and Panneerselvam, R. (2009) Drought Stress in Plants. A Review on Morphological Characteristics and Pigments Composition. International Journal of Agriculture and Biology, 11, 100-105.

[11] Azam, F., Ashraf, M., Ashraf, M.Y. and Iqbal, N. (2005) Effect of Exogenous Application of Glycinebetaine on Capitulum Size and Achene Number of Sunflower Under Water Stress. International Journal of Biology and Biotechnology, 2, 765-771.

[12] Ashraf, M. and Follad, M.R. (2007) Roles of Glycine Betaine and Proline in Improving Plant Abiotic Stress Resistance. Environmental and Experimental Botany, 59, 206-216.

[13] Jaffar, Z.M., Farooq, M., Cheema, M.A., Afzal, I., Basra, S.M.A., Wahid, M.A., Aziz, T. and Shahid, M. (2012) Improving the Performance of Wheat by Seed Priming Under Saline Conditions. Journal of Agronomy and Crop Science, 198, 38-45. https://doi.org/10.1111/j.1439-037X.2011.00485.x

[14] Razzaq, A., Imran, M., Javed, I., Abdul, Q., Muhammad, R. and Muhammad, A. (2013) Enhancing Drought Tolerance of Wheat through Chemical Priming. Wulfenia, 20, 44-56.

[15] Khan, S.U., Bano, A., Jalal-ud-Din, D. and Gurmani, A.R. (2012) Abscisic Acid and Salicylic Acid Treatment as Potent Inducer of Drought Tolerance in Wheat. Pakistan Journal of Botany, 44, 43-49.

[16] Evazi, A. (2012) Induction of Drought Tolerance with Seed Priming in Wheat Cultivars. Acta Agriculturae Slovenica, 99, 21-29.

[17] Ghiyasi, M. and Tajbakhsh M. (2013) Osmopriming Alleviates Drought Stress in Soybean (Glaycine max. I) Seeds during Germination and Early Growth Stages. Journal of Applied Biological Sciences, 7, 35-41. 
Submit or recommend next manuscript to SCIRP and we will provide best service for you:

Accepting pre-submission inquiries through Email, Facebook, LinkedIn, Twitter, etc. A wide selection of journals (inclusive of 9 subjects, more than 200 journals)

Providing 24-hour high-quality service

User-friendly online submission system

Fair and swift peer-review system

Efficient typesetting and proofreading procedure

Display of the result of downloads and visits, as well as the number of cited articles Maximum dissemination of your research work

Submit your manuscript at: http://papersubmission.scirp.org/

Or contact ajps@scirp.org 